\title{
Community metabolism and nutrient cycling at Gray's Reef, a hard bottom habitat in the Georgia Bight*
}

\author{
Charles S. Hopkinson, Jr ${ }^{1}$, Robert D. Fallon ${ }^{2}$, Bengt-Owe Jansson ${ }^{3}$, \\ Joseph P. Schubauer ${ }^{4}$ \\ ${ }^{1}$ Ecosystems Center, Marine Biological Laboratory, Woods Hole, Massachusetts 02543, USA \\ ${ }^{2}$ E. I. DuPont de Nemours and Company, Wilmington, Delaware 19880, USA \\ ${ }^{3}$ Askö Laboratory, University of Stockholm, S-106 91 Stockholm, Sweden \\ ${ }^{4}$ Chesapeake Biological Laboratory, University of Maryland, Solomons, Maryland 20688, USA
}

\begin{abstract}
Benthic and pelagic metabolism and nutrient fluxes were measured during summer on a hard bottom on the continental shelf of the Georgia Bight. USA. Internal pools of organic matter and nutrients in the sediments and water column were also measured and compared with physical transport associated with ocean currents. Gray's Reef is a heterogeneous system consisting of a mosaic of bare sand regions, hard bottom regions thinly veneered with shifting sands, and exposed rock outcrops. Sediment organic carbon content increased from $<0.2 \%$ of dry weight in sandy regions to an epifaunal biomass $>77 \mathrm{~g} \mathrm{C} \mathrm{m}^{-2}$ on rock outcrops. Sponges and corals accounted for a large percentage of macrofaunal biomass when sands were shallow. Benthic metabolism and nutrient regeneration were positively related to the spatial distribution of epifaunal biomass. In regions of high epifaunal biomass respiration exceeded $133 \mathrm{mg} \mathrm{C} \mathrm{m} \mathrm{m}^{-2} \mathrm{~d}^{-1}$ and nutrient flux amounted to $23 \mathrm{mmol}$ inorganic $\mathrm{N}, 1.8 \mathrm{mmol}$ inorganic $P$, and 24 and $0.4 \mathrm{mmol} \mathrm{m} \mathrm{m}^{-2} \mathrm{~d}^{-1}$ dissolved organic $\mathrm{N}$ and $\mathrm{P}$, respectively. The benthic community of Gray's Reef was markedly heterotrophic, consuming almost twice as much organic matter as was produced on the bottom (production : respiration $=0.52 \cdot 1$ ). Community respiration in the water column exceeded by ca $30 \%$ a fairly high level of pelagic primary production of $2.15 \mathrm{~g} \mathrm{C} \mathrm{m}^{-2} \mathrm{~d}^{-1}$ The overall Gray's Reef system was heterotrophic and strongly dependent on allochthonous organic carbon for support of almost one third of its total respiratory requirements (production : respiration $=0.68 \cdot 1$ ). A large percentage $(>50 \%)$ of system biomass and respiration was attributable to filter-feeding organisms which are largely ungrazed, including corals and sponges. A net effect of this hard bottom system was the capture and removal of organic matter produced in the water column. As most of the macrofauna is ungrazed, this organic matter becomes unavailable for support of food chains leading to the production of commercially important fishes. We present some thoughts on the relationship between hard bottoms, in general, and the anomalously low level of fishery production in the Georgia Bight as a whole.
\end{abstract}

\section{INTRODUCTION}

Hard bottom communities, relatively common ecological features of the continental shelf in the Georgia Bight of the southeastern USA, contain biological assemblages consisting of sessile emergent invertebrates such as hard and soft corals, hydroids, anemones, ascidians, sponges, and bryozoans living upon and attached to naturally occurring hard or rocky forma- Contribution No. 667 from the University of Georgia Marine
Institute tions. The term 'hard bottom' is synonymous with the vernacular patch reef, live bottom, coral patches, algal (lithamnion) reef, limestone reef, fishing banks and snapper banks. Due to aggregations of demersal and pelagic fishes in substantially higher densities than in adjacent bare sand regions, hard bottoms are economically valuable systems on the continental shelf which support a recreational fishery in South Carolina and Georgia of over $\$ 25$ million annually. Although unquantified, these sites have a high presumed potential for further commercial development (NOAA 1983). To insure continued vitality of hard bottom com- 
munities in the Georgia Bight, an understanding of ecosystem function is desirable. Yet, ecological information on these systems is for the most part limited to aspects of continental shelf geology and geomorphology and qualitative and semi-quantitative inventories of resident flora and fauna (Pearse \& Williams 1951, Menzies et al. 1966, Cain 1972, Searles 1981, Wenner et al. 1983, 1984).

Current understandings of reef systems, derived almost solely from tropical and subtropical coral reef studies (Kinsey 1985, Smith 1988), indicate that although community metabolic rates can be high (exceeding $6 \mathrm{~g} \mathrm{C} \mathrm{m}^{-2} \mathrm{~d}^{-1}$ ) due to a juxtaposition of zones of autotrophic and heterotrophic subsystems, net or 'new' carbon production for overall reef ecosystems is essentially zero. As coral reefs generally exist in lownutrient environments, low net production relative to high gross production is indicative of the efficiency of coral reefs in internally recycling metabolic products such as nutrients. Lacking a net supply of new inorganic nutrient reactants, the absence of significant net production indicates that organic matter, either in a live (fish biomass) or dead form (detritus), cannot be exported on a sustainable basis without depleting natural reserves of the system.

Hard bottom communities of the Georgia Bight are structurally allied with the better-studied tropical coral reef ecosystems. However, it may not be appropriate to extrapolate understandings of functional aspects of tropical coral reefs to temperate hard bottom communities. Indeed the systems-level paradigm of coral reef behavior is at odds with the presumed commercial fisheries value of hard bottom communities in the Georgia Bight. There cannot be a sustainable hard bottom fishery without substantial levels of net production or organic matter subsidy.

Here we present the first direct estimates of community metabolism and nutrient regeneration in the water column and the sediments at Gray's Reef, a hard bottom region on the continental shelf of the Georgia Bight. To our knowledge, it is the first in situ community metabolism study of a deep, offshore hard bottom community. Although having the character of a snapshot in time, this study presents an unusually complete and coherent picture of a complex benthic-pelagic system, with data collected for the major storages and flows. This allows a discussion of the trophodynamic properties of an offshore reef system, which should stimulate thinking and similar studies on other hard bottom systems.

Also reported are estimates of organic matter and nutrient fluxes across Gray's Reef, the relative importance of benthic and pelagic production and nutrient cycling, and preliminary measures of the metabolic importance of the conspicuous macrofauna. Finally we present some thoughts on the relationship between hard bottoms and fishery production within the overall Georgia Bight region.

\section{STUDY AREA}

The broad and gently sloping south Atlantic continental shelf of the USA varies in width from $<20 \mathrm{~km}$ at its northern and southern ends to $>130 \mathrm{~km}$ off Georgia. The shelf sea floor is generally smooth sand, with an infrequent occurrence of irregular topography due to erosion and deposition processes (Uchupi 1967). Hard bottoms are 'reefs', of either sedimentary or biological origin, which express relief above the bottom and which may or may not be buried under superficial sediments of varying thickness. Hard bottoms are distributed in an unpredictable pattern from the nearshore zone to the shelf edge. They are generally less common and of lower relief nearshore due to the deposition of recent sediments and the scouring effects of river channeling during periods of lower sea level. Further geological description can be found in Henry \& Giles (1980) and references cited therein.

Gray's Reef (Hunt 1974) is one of the few hard bottom areas in the Georgia Bight in which bathymetry, hard-ground morphology, geology and origin have been studied to even a limited extent. The reef (Fig. 1) is located ca $32 \mathrm{~km}$ E of Sapelo Island in about $20 \mathrm{~m}$ of water and covers ca $43 \mathrm{~km}^{2}$ (NOAA 1980). Seismic studies reveal a shallow hard bottom reflector extending seaward from the coast to the vicinity of Gray's Reef, where it projects above the sediment and forms the substrate for hard bottom community establishment (Hunt 1974). Unlike reefs deposited by calcareous coral or algae, Gray's Reef consists of a layer of dolomitized limestone rock deposited during the Miocene era.

Morphological features include ridges, overhanging ledges, caves and sandy rock-littered troughs which generally run in a SW to NE direction (Hunt 1974). Exposed rock ridges and ledges have high densities of sessile flora and fauna. It is generally considered that a decreasing density of sessile organisms with increasing distance from ledges is due to a concomitant increase in the depth of sand covering the hard bottom (Nick Nicholson, Georgia Department of Natural Resources, pers. comm.; author's per. obs.). The relative areas occupied by bare sand and by low and medium density hard bottom within Gray's Reef are 53, 13 and 34\% respectively (Georgia Department of Natural Resources Map). High-density areas, although visually significant, are generally confined to a narrow 2 to $4 \mathrm{~m}$ wide zone paralleling hard bottom ridges within the medium-density region. 


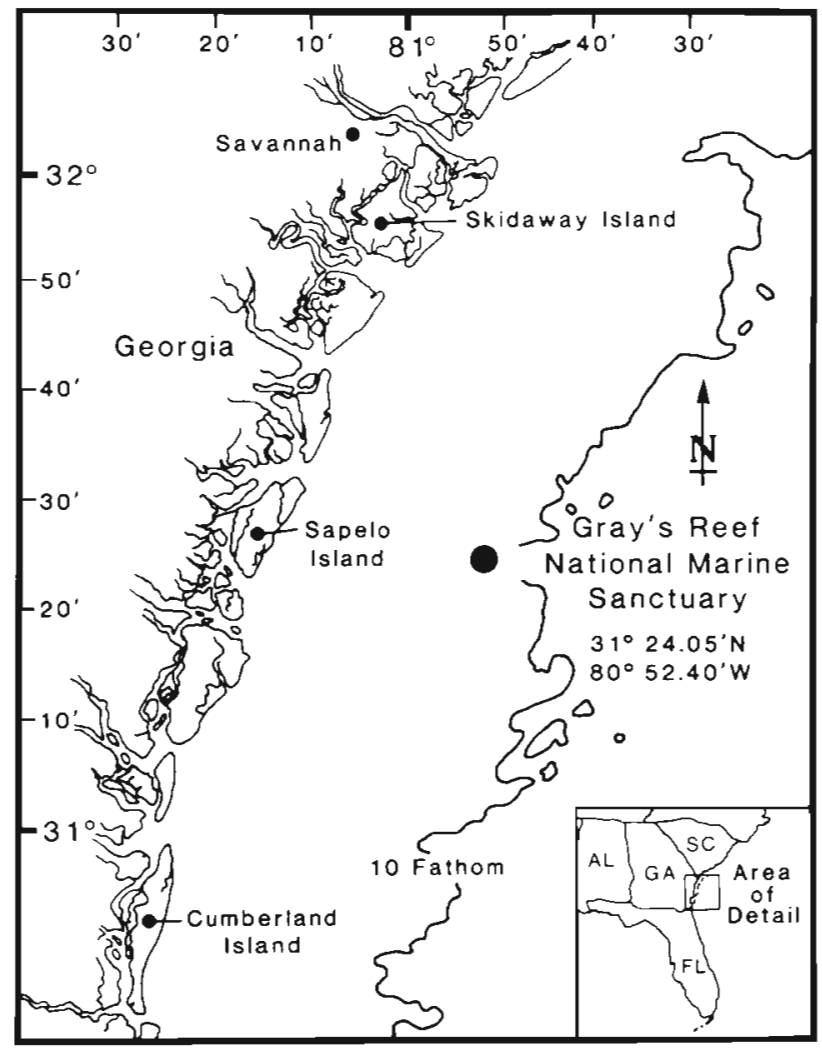

Fig. 1. Location of Gray's Reef National Marine Sanctuary on the continental shelf of the Georgia Bight, USA

Gray's Reef was incorporated into the U.S. National Marine Sanctuary Program in 1982.

\section{METHODS}

During 1983 to 1985 , several exploratory dives were made on Gray's Reef to choose sites representative of medium- and low-density hard bottom areas and bare sandy areas within the boundaries of Gray's Reef National Marine Sanctuary. Metabolic measurements were conducted during a 1 wk period during July 1985. As part of the study, General Oceanics (Miami, Florida, USA) deployed a pair of current meters (GO $6011 \mathrm{MK1}$ ) on fixed moorings at 6 and $15 \mathrm{~m}$ below the water surface, ca $50 \mathrm{~m} \mathrm{SE}$ of the study site.

Site selection. A region with both medium- to highdensity hard bottom and low-density sand-covered hard bottom in close proximity was chosen (Loran C coordinates $61670 \times 44460$ ). Based on observations by the Coastal Resources Division, Georgia Department of Natural Resources (Nick Nicholson pers. comm.), an area at the NE corner of the moderate-relief hard bottom region (Loran $C$ coordinates $61670 \times 44460$ ) was chosen as a study site (Fig. 2). It demonstrated relief typical of the reef in general and was infrequently

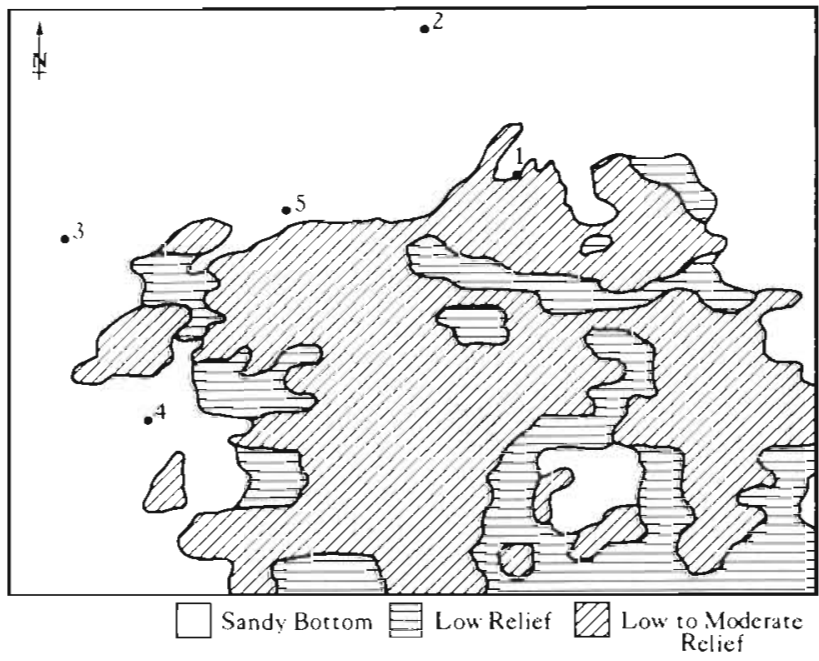

Fig. 2. Gray's Reef National Marine Sanctuary, indicating the station where pelagic and benthic work was conducted (Stn 1). Current meters were placed $50 \mathrm{~m}$ SE of Stn 1. Water was collected for Eulerian measurements at Stns 1 through 5

visited by recreational fishermen and divers. Low- and medium-density sites were chosen by correlating epifaunal density with previous photographic surveys where these bottom types were described.

Community description. Epibiota were sampled from low- and medium-density areas. At the lowdensity sites, all macro-organisms were collected from within domes used for measuring metabolism $\left(0.28 \mathrm{~m}^{2}\right)$ at the conclusion of metabolic measurements. In the medium-density region, four $0.25 \mathrm{~m}^{2}$ triangular quadrats were dropped randomly by diver, and all macroorganisms were collected. In addition, sponge biomass inside the domes in the medium-density area was estimated from photographs to preserve these areas for future work. Organisms were refrigerated until returned to the lab and then frozen at $-14^{\circ} \mathrm{C}$. Prior to drying, organisms were divided into 4 categories: (1) sponge, (2) coral, (3) plant, and (4) miscellaneous. Dry weights $\left(60^{\circ} \mathrm{C}\right.$ until constant weight) and ash-free dry weights $\left(450^{\circ} \mathrm{C}\right.$ overnight) were determined gravimetrically.

To quantify the relative occurrence of the 2 dominant taxa, sponges and corals, census work was undertaken in the general area around where metabolic studies were conducted. A rectangle of plastic tubing, $59 \times$ $78 \mathrm{~cm}$, was successively moved along a baseline running parallel to the edge of the reef ledge. Within each of the density classes (low, medium and high), 16 quadrats for the low- and 10 each for the medium- and high-density areas were analyzed as to coverage of sponges, corals, miscellaneous and bare sand.

\section{Benthos.}

Standing stocks: Sediment cores were collected from the low-density region using cut-off plastic syringes 
(2.65 cm diameter). After recovery of the sediment sample, black rubber stoppers were used to close the syringe. These cores were frozen $\left(-14^{\circ} \mathrm{C}\right)$ upon return to the surface. For analysis, the cores were thawed and cut and extruded into $1 \mathrm{~cm}$ deep sections. Water content, dry weight, and percent ash-free dry weight $\left(450^{\circ} \mathrm{C}\right.$ overnight) were determined gravimetrically. Dissolved nitrite-nitrate, dissolved reactive phosphorous and exchangeable ammonium were determined in pore water from $1 \mathrm{~cm}$ sections (see 'Analytical techniques' below).

To determine the composition of the bulk hard bottom material, a small section of consolidated reef material was recovered (ca $25 \mathrm{~kg}$ dry wt). Ash-free dry weight $\left(450^{\circ} \mathrm{C}\right.$ overnight) was determined for: (1) homogenized bulk material, (2) outer layer $(0$ to $2.5 \mathrm{~cm}$ deep, contains high percentage of encrusting organisms), (3) mid-layer (2.5 to $10 \mathrm{~cm}$ deep, contains mostly consolidated rock with some animal contamination), and (4) core layer (center of recovered piece). No dissolved-nutrient analyses were done for this section.

Sediment metabolism: Benthic metabolism was determined following the technique described by Hopkinson (1985) with in situ measurements of benthic oxygen production and uptake using 3 or 4 belljars in 2 different portions of the hard bottom at Gray's Reef: a sandysubstrate, low-faunal-density area and an area of medium faunal density with very little bare sand substrate. In the low-density area, 3 acrylic hemispheres (domes) covering $0.28 \mathrm{~m}^{2}$ of bottom surface were carefully placed by SCUBA divers ensuring a minimum of sediment disturbance (Fig. 3). Due to the thinness of the sandy substrate overlying the hard bottom, the $6 \mathrm{~cm}$ long vertical aluminum skirts of the domes did not fully penetrate into the sand. Dome volume was therefore determined by measuring the dilution of a known volume of rhodamine dye injected into the water enclosed within the dome.

In the topographically rough, medium-density area, 2 flexible, mylar plastic-sided domes were placed by SCUBA divers onto level, concrete rings which had been attached to the hard bottom 1 mo beforehand. Concrete rings (Fig. 4) were constructed using a $6.4 \mathrm{~cm}$ high by $92 \mathrm{~cm}$ diameter circular PVC frame with an internal frame width of $7.6 \mathrm{~cm}$. The concrete was completely and permanently attached to the hard bottom. Domes consisted of a ca $30 \mathrm{~cm}$ high mylar plastic cylinder attached to a $10 \mathrm{~cm}$ high by $96 \mathrm{~cm}$ diameter PVC ring on the bottom and a circular sheet of clear $0.32 \mathrm{~cm}$ thick by $100 \mathrm{~cm}$ diameter acrylic plastic on the top (Fig. 5). A gasket of seawater-aged foam rubber was placed between the concrete ring and the PVC base of the dome. Portals within the acrylic top sheet enabled access to internal water. The acrylic sheet was suspended above the bottom by a small 1 to 21 volume styrofoam float. Water currents caused the dome to sway back and forth, ensuring that water within the dome was well mixed. As with the low-density domes, dome volume was determined by dilution of a known injection of rhodamine dye.

Dissolved oxygen concentration was monitored either with self-stirring oxygen electrodes or by the

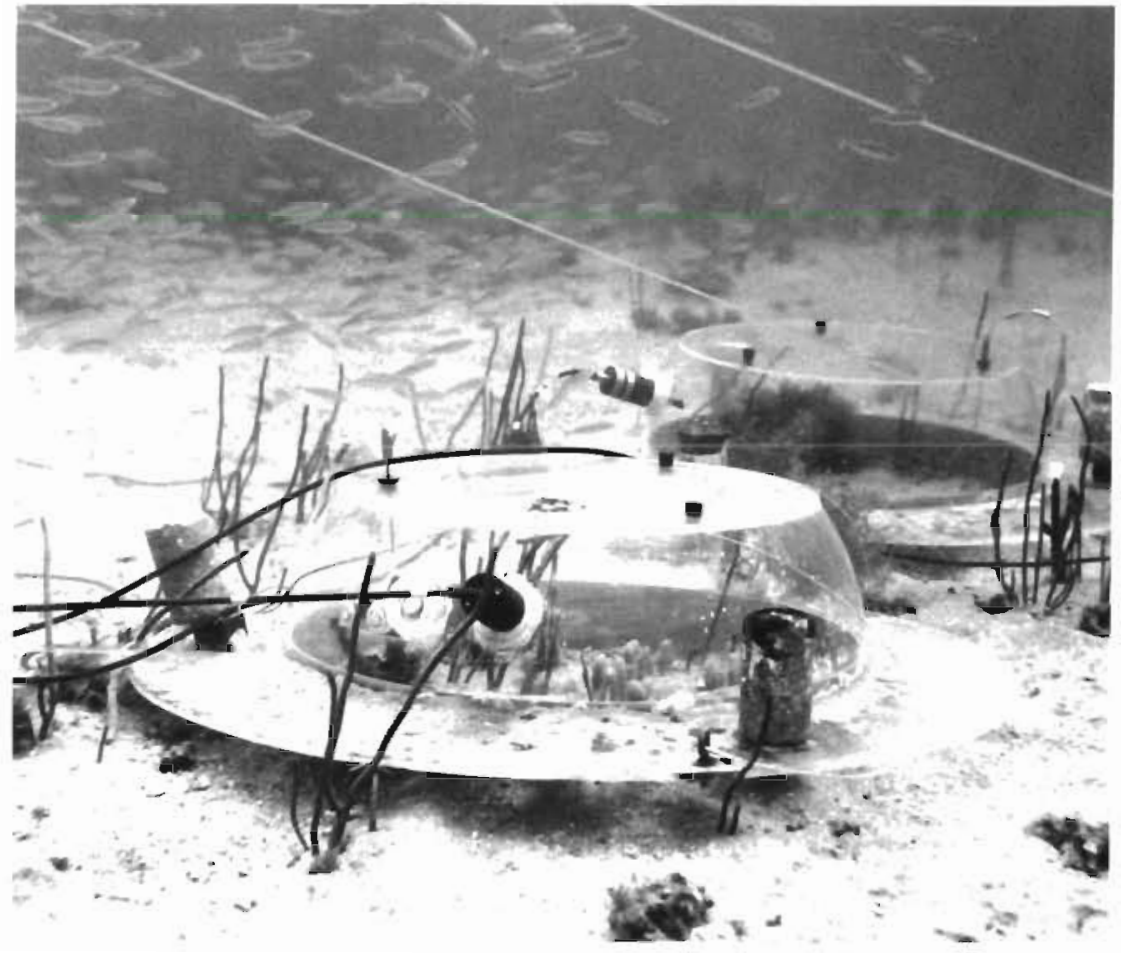

Fig. 3. Low-density site at Gray's Reef at $20 \mathrm{~m}$ depth with domes in place for measuring benthic nutrient fluxes. The oxygen electrode is inserted through the side of the dome and syringe canulas allow attachment of plastic tubing running to the surface for water sampling. The long whips in the photo are the bright orange gorgonacean Titanideum frauenfeldii, and inside the closest dome the above-ground fingers of the yellow pancake sponge Halichondria bowerbanki are seen. Note the high density of pelagic fish 
Fig. 4. Concrete rings which were poured in place over the medium-density portions of the hard bottom substratum at Gray's Reef. Rings allowed benthic chambers to be positively sealed with the substratum, thereby preventing exchange with the overlying water. Typical reef organisms are: (A) the sponge Homaxinella sp., (B) the gorgonacean coral Lophogorgia hebes, (C) a colony of Bryozoa, (D) the basket sponge Ircinia campana, and (E) feather-like hydroids

Fig. 5. Flexible chamber for measuring benthic metabolism and nutrient regeneration at the medium-density site at Gray's Reef. Flexible nature allows wave- and current-induced turbulence to be transmitted into the chamber
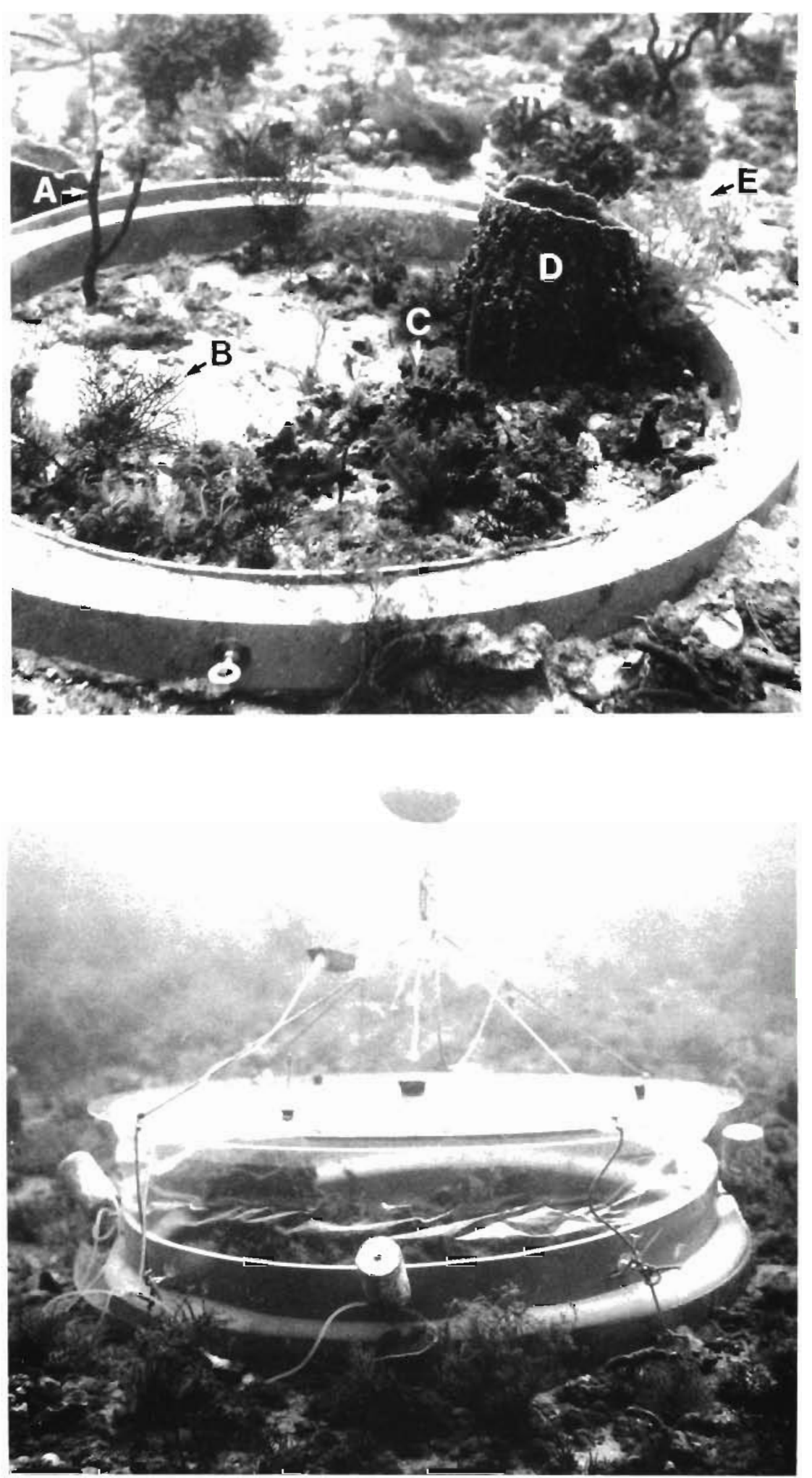

Winkler technique. Dissolved oxygen was measured continuously for about $36 \mathrm{~h}$, after which it was measured discontinuously for an additional 1-night and 2- day period. BOD (biological oxygen demand) bottles were filled contemporaneously with dome placement to provide a correction for oxygen changes due to 
metabolism in the water enclosed in each dome. Seawater in the domes was carefully replenished about every 12 h to minimize enclosure effects.

After correcting for water-column metabolism, benthic community primary production and respiration were estimated by regressing dissolved oxygen concentration against time and then multiplying by dome volume:surface area ratios. Community respiration was determined only in the dark at night. Net daytime community production was the net change in dissolved oxygen during daylight hours. Gross community primary production was the time-weighted sum of net daytime production and nighttime respiration. Net community production was calculated as the balance between gross production and respiration over a $24 \mathrm{~h}$ period.

Nutrient flux across sediment/water interface: Net fluxes of dissolved organic and inorganic nitrogen and phosphorous between the sediment and overlying water were measured in domes contemporaneously with metabolic measurements (Hopkinson 1987). Water samples $(<60 \mathrm{ml})$ were pumped from the surface through narrow-bore tubing with the low-density domes (see Fig. 3) and collected by divers with $60 \mathrm{ml}$ syringes from the medium-density domes. Water samples were collected at intervals ranging from 2 to $6 \mathrm{~h}$. Replacement water entered through small dome-top ports during sample withdrawal to avoid interstitial water exchange. All samples for nutrient analysis were filtered through precombusted, prerinsed glass-fiber filters (Gelman A/E) immediately after collection and transported frozen to the laboratory. Samples for ammonium analysis were fixed with reagents in the field (see below, 'Analytical techniques'). Net nutrient flux was determined by regression of nutrient concentration against time after correction for water-column activity measured in BOD bottles. Rates were put on an areal basis by taking into consideration the volume: surface area ratios of the 2 types of domes.

Water column.

Concentrations and fluxes of nutrients across Gray's Reef: In order to evaluate influences of the benthos on the chemical make-up of water passing over Gray's Reef, surface and near-bottom water samples were collected at 5 sites within a rectangular grid overlaying a large portion of Gray's Reef (Fig. 2). The grid was situated so that faces were perpendicular to the primary cross-shore and along-shore current directions. Water samples were collected approximately every $2 \mathrm{~h}$ over a $12.5 \mathrm{~h}$ tidal cycle. Water samples were filtered through Whatman GF/C filters and, with the exception of ammonium which was analyzed on ship, frozen until analysis. Samples were analyzed for $\mathrm{NH}_{4}^{+}, \mathrm{NO}_{2}^{-}$and $\mathrm{NO}_{3}^{-}, \mathrm{PO}_{4}^{3-}$, dissolved organic nitrogen (DON), dissolved organic carbon (DOC) and chlorophyll a (chl a).
Gross nutrient transport across Gray's Reef or net nutrient uptake or release was calculated from concurrent measurements of current velocities (see Appendix 1 in Fallon \& Hopkinson 1986) and the spatial and temporal pattern of nutrient concentrations across the sampling grid.

Pelagic primary production: Pelagic primary production was estimated by ${ }^{14} \mathrm{CO}_{2}$ incorporation during $4 \mathrm{~h}$ onboard incubations at 5 light levels $(100,61,48,23$, and $5 \%$ of surface light) and in situ temperature $\left(28^{\circ} \mathrm{C}\right)$ (Strickland \& Parsons 1972). Surface light was integrated over the day, while vertical profiles of photosynthetically, active radiation were measured every few hours throughout the day with a LICOR spherical submarine detector. Particulate ${ }^{14} \mathrm{C}$ was collected on $47 \mathrm{~mm}, 0.45 \mu \mathrm{m}$ Millipore HA filters. Dissolved ${ }^{14} \mathrm{C}$ was determined in the filtrate after acidification and $45 \mathrm{~min}$ bubbling to remove inorganic ${ }^{14} \mathrm{C}$ (Peterson 1978). Radioactivity was determined by liquid scintillation counting with H-number (Beckman) quench correction. Primary production was measured on 2 separate days and depth-integrated results were averaged to obtain a single primary production estimate for the water column.

Pelagic respiration: Pelagic metabolism was measured in vitro by monitoring dissolved oxygen uptake in 3 opaque, 201 polyethylene carboys incubated in the laboratory within $1{ }^{\circ} \mathrm{C}$ of ambient temperatures. Water was collected by pumping water from throughout the water column through a $2 \mathrm{~cm}$ diameter plastic hose with an $81 \mathrm{~min}^{-1}$ diaphragm pump. Dissolved oxygen was measured periodically for $17 \mathrm{~h}$ with an oxygen probe (YSI-Clark electrode). Pelagic community metabolism was calculated by regressing dissolved oxygen concentration against time. Rates were expressed on an areal basis by accounting for water column depth. No attempt was made to examine possible diel patterns in community respiration.

Pelagic $\mathrm{NH}_{4}{ }^{+}$turnover: Pelagic ammonium remineralization was investigated using the isotope dilution technique (Blackburn 1979, Caperon et al. 1979). Water from throughout the water column was collected during mid-morning in a $20 \mathrm{l}$ carboy with a diaphragm. Within 30 min of collection, water was gently siphoned through $208 \mu \mathrm{m}$ screening into four $2.5 \mathrm{l}$ glass reagent bottles. In sequential order, each bottle was amended with ${ }^{15} \mathrm{~N}$ tracer, initially sampled and incubated. Sufficient ${ }^{15} \mathrm{~N}$ - $\left(\mathrm{NH}_{4}\right)_{2} \mathrm{SO}_{4}(99 \%)$ was added to each bottle to make a final concentration of $0.2 \mu \mathrm{M}^{15} \mathrm{~N}$. Immediately after tracer addition, bottles were swirled, a $600 \mathrm{ml}$ sample withdrawn, and the bottles placed in an ondeck flowing seawater incubator covered with neutraldensity screening allowing $25 \%$ light transmission; $75 \mathrm{ml}$ of the sample withdrawn was used to rinse filtering apparatus (including Whatman glass fiber GF/F) 
and polyethylene storage bottles and then discarded. After withdrawing $25 \mathrm{ml}$ for ammonium analysis, the remainder of the filtrate was frozen until further processing on shore. Bottles were resampled 0.5,2 and $3.5 \mathrm{~h}$ after tracer addition.

Ammonium concentration was redetermined (Grasshoff 1976) following thawing, and ammonium was stripped from stored samples within $1 \mathrm{wk}$ of collection at the onshore laboratory. Prior to stripping, $2.0 \mu \mathrm{mol}$ ${ }^{14} \mathrm{~N}-\left(\mathrm{NH}_{4}\right)_{2} \mathrm{SO}_{4}$ carrier was added to the $400 \mathrm{ml}$ sample. The solvent extraction procedure described by Dudek et al. (1986) was used to strip ammonium nitrogen for the determination of relative ${ }^{15} \mathrm{~N}$ abundance. In this procedure ammonium is converted to indophenol using a modification of the phenol-hypochlorite reaction for seawater ammonium analysis. The indophenol is extracted into methylene chloride, concentrated by partial evaporation of the solvent and dried on a glassfiber filter (Whatman $934 \mathrm{AH}$ ). Filters were dried at $80^{\circ} \mathrm{C}$ and stored in plastic scintillation vials. ${ }^{15} \mathrm{~N}$ content was analyzed by emission spectrometry following a modification of the micro-Dumas procedure (Dudek et al. 1986). Filters were ground with $0.5 \mathrm{~g}$ precombusted $\left(500^{\circ} \mathrm{C}\right)$ Cuprox and stored in evacuated vacutainers until placement into a $5 \mathrm{~mm}$ OD pyrex discharge tube containing ca $2 \mathrm{~cm}$ precombusted $\left(900^{\circ} \mathrm{C}\right)$ $\mathrm{CaO}$. The tubes were evacuated to $<10^{-5}$ torr, sealed, combusted for $8 \mathrm{~h}$ at $500^{\circ} \mathrm{C}$ and analyzed on a Jasco emission spectrometer.

Ammonium regeneration rates were calculated from measurements of ammonium concentration and isotope ratio according to the Blackburn (1979) equations (see Laws 1984). Corrections to the measured isotope ratio were made for isotope contamination during sample freezing, ammonium extraction, and micro-Dumas combustion.

Analytical techniques: Inorganic nutrients were analyzed using the colorimetric techniques outlined in Grasshoff (1976): phenol-hypochlorite for ammonium, cadmium reduction followed by sulfanilimide for nitrite and nitrate, ascorbic acid and molybdate for phosphate, and oxidation to nitrate and phosphate for dissolved organic N and P. A Perkin-Elmer Model 240C was used for carbon analyses of particulate samples. Inorganic carbon was removed with weak hydrochloric acid following the technique of Hedges \& Stern (1984). Dissolved oxygen, when measured by the Winkler technique, followed that outlined in Strickland \& Parsons (1972). Chlorophyll was determined by fluorometry (Strickland \& Parsons 1972) on a Turner fluorometer. Pelagic chlorophyll samples were obtained by filtering 900 to $1200 \mathrm{ml}$ onto a Millipore $0.45 \mu \mathrm{m}$, $47 \mathrm{~mm}$ HA filter, dissolving the filter, and extracting $\left(4{ }^{\circ} \mathrm{C}\right.$ overnight) particulates in dimethyl sulfoxide- $90 \%$ acetone (DMSO-acetone) (Shoaf \& Lium 1976). Benthic chlorophyll samples were also collected from the sand and hard bottom areas. Samples averaging $28 \mathrm{~g}$ dry wt were extracted overnight $\left(4^{\circ} \mathrm{C}\right)$ in $150 \mathrm{ml}$ DMSOacetone. The extract was cleansed by centrifugation and chlorophyll measured fluorometrically

Integration of data. An integrated picture for the Gray's Reef Sanctuary system as a whole was calculated by combining pelagic and benthic data. Based on the relative area for each macrofaunal density bottom type and bare sand areas within the sanctuary, mean benthic metabolic rates were calculated as a weighted mean of the areal rates for the various bottom types. Pelagic rates were calculated based on integrating volumetric metabolic data for an assumed average water column depth of $20 \mathrm{~m}$.

\section{RESULTS}

\section{Benthic community description and standing stocks}

A variety of epibiota were collected at both low- and medium-density sites at Gray's Reef (Table 1). Macroalgal material was present at low-and medium-density sites but biomass, estimated from chl a content, was a minor component at both sites (Table 2). Hard corals, Oculina sp. and Astrangia sp., were found only at the medium-density site. Bryozoans and ascidians appeared to be much more important at the mediumdensity site also. Carbon biomass in the miscellaneous category was more important at the medium-density location (Table 2). There was a strong shift in the relative biomass of sponge vs coral in moving from the low- to medium-density site. The biomass distribution going from low-density to medium-density areas shifted from a sponge: coral ratio of 3\%:52\% at the low-density site to $35 \%: 6 \%$ at the medium-density site. Some of the same tendencies were also found in the coverage data (Table 3). The miscellaneous category (bryozoans, hydroids, ascidians, mussels) showed a maximum in the medium-density area, where it covered nearly half the area. The sponge:coral ratio was lowest in the low-density area. In the mediumand high-density areas, however, the sponges and corals had about the same coverage. In general, about half the bottom area in medium- and high-density regions was covered with a combination of sponges and corals.

Although we did not attempt to quantify the amount of fish on the reef, their abundance was conspicuous and they should play a role in structuring the community and in the total metabolism of the reef, both as predators and as nutrient regenerators. Characteristic species were Centropristis striata (black sea bass), Archosargus probatocephalus (sheepshead), Haemu- 
Table 1. Predominant macroflora and fauna observed at sites of benthic metabolism measurement at Gray's Reef

\begin{tabular}{|c|c|}
\hline $\begin{array}{l}\text { Sites } \\
\text { Benthos category }\end{array}$ & Benthos \\
\hline \multicolumn{2}{|l|}{ Low-density site } \\
\hline Sponges & $\begin{array}{l}\text { Homaxinella waltonsmithi, Homaxinella sp., Phakellia lobata, Halichondria bowerbanki, Ciocalapata } \\
\text { gibbsi, Anthosigmella varians }\end{array}$ \\
\hline Soft coral & Titanideum frauenfeidu, Lophogorgia hebes, Telesto fruticulosus \\
\hline Plants & Various red macroalgae \\
\hline Miscellaneous & $\begin{array}{l}\text { Arca zebra, Arca imbricata (encrusted with Balanus sp. and Astrangia astreiformis), various bryo- } \\
\text { zoans, encrusting Ascidiacea (e.g. Diplosoma macdonaldi and Ascidia curvata), various small } \\
\text { decapods, various hydroids, Astrophyton muricatum, Conus sp., Vermicularia knorni, Botrylloides } \\
\text { nigrum, Filograna implexa }\end{array}$ \\
\hline \multicolumn{2}{|l|}{ Medium-density site } \\
\hline Sponges & $\begin{array}{l}\text { Ircinia ramosa, Neofibularia nolitangere, Homaxinella waltonsmithi, Homaxinella rudis, Phakellia } \\
\text { lobata, Ircinia strobilina, Aplysina fistularis, Ircina campana }\end{array}$ \\
\hline Coral & Lophogorgia sp., Titanideum sp., Astrangia sp., Oculina sp., Astrea sp. \\
\hline Plants & Various red and brown macroalgae \\
\hline Miscellaneous & $\begin{array}{l}\text { Various bryozoans, various Ascidiacea (e.g. Diplosoma macdonaldi, Styela plicata, Diplosoma sp., } \\
\text { Ascidia curvata, Botrylloides nigrum), various hydroids, Arca sp., Astrea sp., Chama congregata, } \\
\text { various decapods, Batroides sp., Ocnus pygmaeus, various crinoids, Ostrea permolis, Filograna } \\
\text { implexa }\end{array}$ \\
\hline
\end{tabular}

Table 2. Benthic pools of selected chemical components at Gray's Reef. For the categories distinguished in sorting the epibiota components carbon distributions were as follows. Low-density: Sponge, $3 \%$; Coral, $52 \%$; Plant, trace; Miscellaneous, $45 \%$. (This distribution was calculated excluding the contribution of the pancake sponge Halichondria bowerbanki, as it was found in only 1 of 3 samples and was not visually important in the surrounding area. With this material added, average carbon in the epibiota was ca $39 \mathrm{~g} \mathrm{C} \mathrm{m}^{-2}$.) Medium-density: Sponge, $35 \%$; Coral, $6 \%$; Plant, $1 \%$ Miscellaneous, $58 \%$. n.e.. not evaluated in limestone substrate

\begin{tabular}{|c|c|}
\hline $\begin{array}{l}\text { Sites } \\
\text { Component }\end{array}$ & Standing stock \\
\hline \multicolumn{2}{|l|}{ Low-density site } \\
\hline \multicolumn{2}{|l|}{ Organic carbon } \\
\hline Sand sediment (to $6 \mathrm{~cm}$ deep) & $570 \mathrm{~g} \mathrm{C} \mathrm{m}^{-2}$ \\
\hline Epibiota & $27.2 \mathrm{~g} \mathrm{C} \mathrm{m}^{-2}$ \\
\hline \multicolumn{2}{|l|}{ Chlorophyll } \\
\hline Sand (surface to $4 \mathrm{~cm}$ deep) & $869 \mathrm{mg} \mathrm{chl} a \mathrm{~m}^{-2}$ \\
\hline \multicolumn{2}{|l|}{ Dissolved nutrients } \\
\hline $\mathrm{NH}_{4}^{+}$ & $57 \mathrm{mg} \mathrm{NH}_{4}^{+}-\mathrm{N} \mathrm{m}^{-2}$ \\
\hline $\mathrm{NO}_{2}^{-}+\mathrm{NO}_{3}^{+}$ & $27.7 \mathrm{mg} \mathrm{NO}{ }_{3}^{-}-\mathrm{N} \mathrm{m}^{-2}$ \\
\hline $\mathrm{PO}_{4}^{3-}$ & $107.9 \mathrm{mg} \mathrm{PO}_{4}^{3-}-\mathrm{P} \mathrm{m}^{-2}$ \\
\hline \multicolumn{2}{|l|}{ Medium-density site } \\
\hline \multicolumn{2}{|l|}{ Organic carbon } \\
\hline Reef substrate (to $3 \mathrm{~cm}$ deep) & $673 \mathrm{~g} \mathrm{C} \mathrm{m}^{-2}$ \\
\hline Epibiota & $77.2 \mathrm{~g} \mathrm{C} \mathrm{m}^{-2}$ \\
\hline \multicolumn{2}{|l|}{ Chlorophyll } \\
\hline Reef face (to $2 \mathrm{~cm}$ deep) & $197 \mathrm{mg} \mathrm{chl} \mathrm{a} \mathrm{m} \mathrm{m}^{-2}$ \\
\hline Dissolved nutrients & n.e. \\
\hline
\end{tabular}

lon aurolineatum (tomtate or white grunt) and Halichoeres bivittatus (slippery dick).

On an areal basis the bulk substratum at both sites dominated the organic carbon distribution (Table 2). Organic carbon in the sand at the low-density site (integrated over the depth down to hard bottom, $\mathrm{ca} 6 \mathrm{~cm}$ ) represented a carbon pool $\left(570 \mathrm{~g} \mathrm{C} \mathrm{m}^{-2}\right)$ almost 15 -fold higher than the carbon contributed by the epibiota (27.2 $\mathrm{g} \mathrm{C} \mathrm{m}^{-2}$ ) (Table 2). A similar situation occurred at the medium-density site, where the substratum (to $3 \mathrm{~cm}$ ) $\left(673 \mathrm{~g} \mathrm{C} \mathrm{m}^{-2}\right)$ contributed almost 9 times as much organic carbon as the epibiota $\left(77.2 \mathrm{~g} \mathrm{C} \mathrm{m}^{-2}\right)$. On an areal basis the organic carbon contribution by epibiota was 3 -fold higher at the medium-density location than at the low-density location. Chlorophyll concentrations showed that there may be a substantial microalgal biomass associated with both substrata

\section{Benthic metabolism}

Community metabolism correlated with the macrofaunal density of the site (Table 4). However, temporal and spatial variability in metabolism was fairly high, as evidenced by rather large coefficients of variation for community respiration and net daytime production (Table 4). Oxygen concentrations never fell below $20 \%$ of saturation during the incubations. At the low-density site, the mean gross primary production (GP) of $313 \mathrm{mg}$ $\mathrm{C} \mathrm{m}^{-2} \mathrm{~d}^{-1}\left(22.4 \mathrm{mg} \mathrm{C} \mathrm{m}^{-2} \mathrm{~h}^{-1}\right)$ was balanced by a mean 
Table 3. Percent coverage by main categories of faunal assemblages in low-, medium- and high-density areas of Gray's Reef. Values in parentheses are standard deviations

\begin{tabular}{|lccc|}
\hline Category & Low density & Medium density & High density \\
\hline Sponges & $0.8(1.5)$ & $22(12.7)$ & $28(11.1)$ \\
Corals & $2.9(2.8)$ & $17.5(10.6)$ & $25(10.5)$ \\
Macroalgae & 0 & $6.3(4.7)$ & $9(7)$ \\
Miscellaneous & $0.6(1.7)$ & $48.2(20.3)$ & $28(9.8)$ \\
Sand & $93.2(5.5)$ & $6(19)$ & $10(7.1)$ \\
Sponge:coral & $0.3: 1$ & $1.3: 1$ & $1.1: 1$ \\
\hline
\end{tabular}

Table 4. Benthic community metabolism of low- and mediumdensity regions of Gray's Reef during summer. Based on $14 \mathrm{~h}$ light: $10 \mathrm{~h}$ dark cycle and respiratory quotient of 1 NR: dark respiration per hour ( $24 \mathrm{~h}$ ); NDP: net daytime production per hour (14 h); GP: gross community production per hour $(14 \mathrm{~h})_{\text {i }}$ NCP: net community production per day. GP $=\mathrm{NDP}+\mathrm{NR}$; $\mathrm{NCP}=(\mathrm{GP} \times 14 \mathrm{~h})-(\mathrm{NR} \times 24 \mathrm{~h})$. Values for NR and NDP are shown \pm coefficient of variation

\begin{tabular}{|c|c|c|c|c|}
\hline Site & $\begin{array}{l}\mathrm{NR} \\
\quad(\mathrm{mg}\end{array}$ & $\begin{array}{c}\mathrm{NDP} \\
\mathrm{C} \mathrm{m}^{-2}\end{array}$ & GP & $\begin{array}{c}\mathrm{NCP} \\
\left(\mathrm{mg} \mathrm{C} \mathrm{m} \mathrm{m}^{-2} \mathrm{~d}^{-1}\right)\end{array}$ \\
\hline Low-density & $\begin{array}{r}13.02 \\
+39 \%\end{array}$ & $\begin{array}{r}9.33 \\
+37 \%\end{array}$ & 22.35 & 0.37 \\
\hline $\begin{array}{l}\text { Medium- } \\
\text { density }\end{array}$ & $\begin{array}{r}133.03 \\
\pm 48 \%\end{array}$ & $\begin{array}{l}-36.41 \\
\pm 36 \%\end{array}$ & 96.62 & -1840 \\
\hline
\end{tabular}

community respiration of $312 \mathrm{mg} \mathrm{C} \mathrm{m}{ }^{-2} \mathrm{~d}^{-1}(13.0 \mathrm{mg}$ $\mathrm{C} \mathrm{m}^{-2} \mathrm{~h}^{-1}$ ), resulting in a net community production rate of $0.37 \mathrm{mg} \mathrm{C} \mathrm{m}^{-2} \mathrm{~d}^{-1}$, which is not significantly different from zero. GP at the medium-density location averaged $97 \mathrm{mg} \mathrm{C} \mathrm{m}{ }^{-2} \mathrm{~h}^{-1}$, more than 4 times higher than at the low-density location. However, net daytime production averaged $-36 \mathrm{mg} \mathrm{Cm}^{-2} \mathrm{~h}^{-1}$ and respiration averaged $133 \mathrm{mg} \mathrm{C} \mathrm{m}{ }^{-2} \mathrm{~h}^{-1}$. Thus, the mediumdensity region was heterotrophic, with net community production averaging $-1.84 \mathrm{~g} \mathrm{C} \mathrm{m}^{-2} \mathrm{~d}^{-1}$.

\section{Benthic nutrient flux}

Low-density region

Sediments and benthos were a source of inorganic nutrients for the overlying water column during both light and dark periods of the day (Table 5). Ammonium dominated the flux of nitrogenous compounds, averaging $526 \mu \mathrm{mol} \mathrm{N} \mathrm{m}{ }^{-2} \mathrm{~d}^{-1}$. Fluxes of $\mathrm{NO}_{2}^{-}+\mathrm{NO}_{3}^{-}$represented ca $32 \%$ of total inorganic nitrogen flux. Phosphate fluxes were comparable in magnitude to the flux of nitrite-nitrate. The ratio of inorganic nitrogen to phosphorous flux averaged 3.6:1 over a $24 \mathrm{~h}$ period. There were no differences in nutrient flux between light and dark periods (data not shown). The ratio of inorganic nitrogen to inorganic phosphorous fluxes was
Table 5. Benthic nutrient flux from low-and medium-density portions of Gray's Reef during summer. Positive values represent fluxes from sediment to water. DON: dissolved organic nitrogen; DOP: dissolved organic phosphorus. TIN (total inorganic nitrogen) $=\mathrm{NH}_{4}^{+}+\mathrm{NO}_{2}^{-}+\mathrm{NO}_{3}^{-}$

\begin{tabular}{|c|c|c|c|}
\hline \multirow{3}{*}{ Constituent } & \multicolumn{3}{|c|}{ Flux } \\
\hline & \multirow{2}{*}{$\begin{array}{l}\text { Low-density } \\
\left(\mu \mathrm{mol} \mathrm{m} \mathrm{m}^{-2} \mathrm{~d}^{-1}\right)\end{array}$} & \multicolumn{2}{|c|}{ Medium-density } \\
\hline & & $\begin{array}{l}\text { Day } \\
\text { (mmol }\end{array}$ & $\begin{array}{l}\text { Night } \\
\left.d^{-1}\right)\end{array}$ \\
\hline $\mathrm{NH}_{4}^{+}$ & 526 & 13.7 & 21.5 \\
\hline $\mathrm{NO}_{2}^{-}+\mathrm{NO}_{3}^{-}$ & 240 & 4.8 & 6.4 \\
\hline $\mathrm{PO}_{4}^{3-}$ & 215 & 1.6 & 2.0 \\
\hline DON & -21 & 14.3 & 34.0 \\
\hline DOP & 63 & -0.34 & 1.22 \\
\hline TIN & 766 & 18.5 & 27.9 \\
\hline TIN : $\mathrm{PO}_{4}^{-}$ & $3.6: 1$ & $12.6: 1$ & $14.0: 1$ \\
\hline
\end{tabular}

much lower at the low-density than at the mediumdensity location (Table 5).

Medium-density region

Nutrient fluxes from the medium-density sites were high and the direction was always from bottom to overlying water (Table 5). DON dominated the flux of nutrients, followed by ammonium, nitrite-nitrate, phosphate and dissolved organic phosphorous (DOP). In general, fluxes were greater at night than during the day. The ratio of inorganic nitrogen to phosphorous fluxes varied from ca 8:1 to 17.3:1 and averaged 14:1.

Estimates of mean benthic nutrient flux at Gray's Reef, taking into consideration the relative areas of bare sand and low-and medium-density hard bottom, were (in mmol $\mathrm{N}$ or $\mathrm{P} \mathrm{m}^{-2} \mathrm{~d}^{-1}$ ): $\mathrm{NH}_{4}^{+}, 6.33 ; \mathrm{NO}_{3}^{-}, 2.06$; DON, 8.21; $\mathrm{PO}_{4}^{3-}, 0.75 ; \mathrm{DOP}, 0.19$.

\section{Standing stocks of $\mathrm{C}$ and $\mathrm{N}$ in the water column}

Particulate carbon in the water column was calculated at $64 \mathrm{mmol} \mathrm{C} \mathrm{m}^{-2}$ (equivalent to $38.4 \mathrm{mg} \mathrm{m}^{-3}$ ) 
Table 6. Pools of particulate and dissolved components in the water column at Gray's Reef ( $20 \mathrm{~m}$ deep water column). POC: particulate organic carbon; PN: particulate nitrogen; DON: dissolved organic nitrogen; DOP: dissolved organic phosphorus

\begin{tabular}{|c|c|}
\hline Component & Standing stock \\
\hline \multicolumn{2}{|l|}{ Particulates } \\
\hline Chl a & 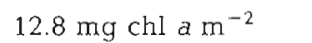 \\
\hline $\mathrm{POC}^{\mathrm{a}}$ & $64 \mathrm{mmol} \mathrm{C} \mathrm{m}^{-2}$ \\
\hline $\mathrm{PN}^{\mathrm{a}}$ & $5.7 \mathrm{mmol} \mathrm{N} \mathrm{m}^{-2}$ \\
\hline \multicolumn{2}{|l|}{ Dissolved } \\
\hline DON-N & $233 \mathrm{mmol} \mathrm{N} \mathrm{m}^{-2}$ \\
\hline DOP-P & $1.9 \mathrm{mmol} \mathrm{Pm}^{-2}$ \\
\hline $\mathrm{NH}_{4}^{+}-\mathrm{N}$ & $7.8 \mathrm{mmol} \mathrm{N} \mathrm{m}^{-2}$ \\
\hline $\mathrm{NO}_{2}^{-} / \mathrm{NO}_{3}^{-}-\mathrm{N}$ & $2.7 \mathrm{mmol} \mathrm{N} \mathrm{m}^{-2}$ \\
\hline $\mathrm{PO}_{4}^{3-}-\mathrm{P}$ & $8.0 \mathrm{mmol} \mathrm{P} \mathrm{m}{ }^{-2}$ \\
\hline \multicolumn{2}{|c|}{$\begin{array}{l}\text { "POC and PN are based on chlorophyll measurements } \\
\text { assuming a chl a:POC weight ratio of } 1: 60 \text { (Parsons et al. } \\
\text { 1984) and a PC:PN molar ratio of 11.3:1 for coastal Georgia } \\
\text { waters at this distance from shore (Haines \& Dunstan } 1975 \text {, } \\
\text { Oertel \& Dunstan 1981) }\end{array}$} \\
\hline
\end{tabular}

(Table 6). Chlorophyll in the water column, $12.8 \mathrm{mg}$ chl a $\mathrm{m}^{-2}$, was substantially lower than the benthic chlorophyll (Tables 2 \& 6). Pelagic nitrogen concentrations were dominated by the DON pool, $232 \mathrm{mmol} N$ $\mathrm{m}^{-2}$. On an areal basis the inorganic nitrogen and phosphorous pools in the water column were similar to those estimated for the interstitial waters of the sandy sediments at the low-density site (Tables $2 \& 6$ ).

\section{Pelagic primary production}

Calculated from PAR (photosynthetically available radiation) depth profiles, the light attenuation factor $k$ (in meters) in the water column was -0.0705 . Surface light levels on seasonally typical days exceeded $2000 \mu \mathrm{E}$ $\mathrm{m}^{-2} \mathrm{~s}^{-1}$. Maximal photosynthesis occurred at light levels equivalent to $2-4 \mathrm{~m}$ depth, suggesting either inhibition by surface light or algal distribution. The maximum volumetric rate observed over $2 \mathrm{~d}$ during which measurements were made was $35.1 \mu \mathrm{C} \mathrm{Cl}^{-1} \mathrm{~h}^{-1}$, which occurred at a light level equivalent to $2.1 \mathrm{~m}$ depth; $3 \mathrm{~d}$ later the maximum rate, $17 \mu \mathrm{g} \mathrm{C} \mathrm{l}^{-1} \mathrm{~h}^{-1}$, occurred at a light level equivalent to $3.6 \mathrm{~m}$. Integrated over the water column, primary production ranged from 2.0 to $2.3 \mathrm{~g} \mathrm{C} \mathrm{m}^{-2} \mathrm{~d}^{-1}$, which yields an average estimate of $2.15 \mathrm{~g} \mathrm{C} \mathrm{m}^{-2} \mathrm{~d}^{-1}$ for the water column.

\section{Pelagic respiration}

Oxygen consumption in the water column ranged from 0.0159 to $0.0194 \mathrm{~g} \mathrm{O}_{2} \mathrm{~m}^{-3} \mathrm{~h}^{-1}$ and averaged
$0.0172 \mathrm{~g} \mathrm{O}_{2} \mathrm{~m}^{-3} \mathrm{~h}^{-1}$. The rate of oxygen consumption was linear over time (data not shown), indicating relative constancy of pelagic populations and that there was sufficient organic matter to sustain metabolism during the $12 \mathrm{~h}$ interval. Integrated over the water column and assuming a respiratory quotient of 1.0 (Hopkinson 1985), pelagic respiration averaged $2.8 \mathrm{~g}$ $C \mathrm{~m}^{-2} \mathrm{~d}^{-1}$.

\section{Pelagic ammonium recycling}

Remineralization of ammonium in the water column at Gray's Reef during mid-day averaged $0.067 \mu \mathrm{mol}$ $\mathrm{NH}_{4}^{+}-\mathrm{N} \mathrm{l}^{-1} \mathrm{~h}^{-1}$ (Table 7). Assuming a constant regener-

Table 7. Time-course history of incubations for measuring ammonium regeneration

\begin{tabular}{|c|c|c|c|}
\hline $\begin{array}{l}\text { Time } \\
\text { (h) }\end{array}$ & $\begin{array}{c}\mathrm{NH}_{4}^{+} \\
\text {concentration } \\
(\mu \mathrm{M})\end{array}$ & $\begin{array}{c}\text { Isotope ratio } \\
\text { (atom \% excess) }\end{array}$ & $\begin{array}{c}\text { Regeneration } \\
\left(\mu \mathrm{mol} \mathrm{N}^{-1} \mathrm{~h}^{-1}\right)\end{array}$ \\
\hline 0 & 0.54 & 37.60 & \\
\hline 0.5 & 0.54 & 35.96 & 0.048 \\
\hline 2.0 & 0.54 & 31.22 & 0.051 \\
\hline 3.5 & 0.50 & 24.09 & 0.089 \\
\hline
\end{tabular}

ation rate throughout a $24 \mathrm{~h}$ period, ammonium regeneration amounts to $1.5 \mathrm{mmol} \mathrm{N} \mathrm{m}^{-3} \mathrm{~d}^{-1}$. With an average pool size of $0.53 \mathrm{mmol} \mathrm{m} \mathrm{m}^{-3}$ during the experiment, the turnover time of ammonium was $7.9 \mathrm{~h}$.

\section{Advective flux of nutrients across Gray's Reef}

For the month during which the 1985 study occurred, progressive vector representations for wind and topand bottom-current velocities at Gray's Reef indicated a net wind vector of ca $90 \mathrm{~km}$ to the N-NE. Net current vectors were $72 \mathrm{~km}$ to the $E$ for surface water and $75 \mathrm{~km}$ to the N-NW for bottom water (see Fallon \& Hopkinson 1986). Thus, tidal currents and net advective motion were transporting 'new' water on a daily basis. Residence time of water within the $4.5 \times 2.0 \mathrm{~km}$ nutrient sampling grid at Gray's Reef was conservatively estimated (based on advection only and without additional turbulent mixing processes) to range between 0.2 and $1.2 \mathrm{~d}$ (the former based on the average speed of surface and bottom water measured during the time of sampling, and the latter estimate based on the mean velocity of surface and bottom water during the interval 29 May to 26 August). Based on the net excursion of a particle of water during the $12 \mathrm{~h}$ interval of water sample collection, the transit time of water 
across our sampling grid was $0.7 \mathrm{~d}(17 \mathrm{~h})$. This is an underestimate of true turnover time, as we have neg. lected turbulent mixing processes.

In spite of the substantial benthic nutrient fluxes observed (Table 5), we were unable to discern any 'upstream-downstream' concentration gradients in water passing over the reef. This resulted from the rather high degree of small-scale variability in nutrient concentrations, turbulent water movement, the relatively large nutrient stocks in the water column (Table 6) and the short transport time of water across the sampling grid. Intra-site sampling variability (coefficient of variation) was $15 \%$ for DON, $30 \%$ for $\mathrm{NO}_{2}^{-}+$ $\mathrm{NO}_{3}^{-}, 37 \%$ for $\mathrm{NH}_{4}^{+}, 51 \%$ for $\mathrm{PO}_{4}^{3-}$ and $68 \%$ for DOP. Had a homogeneous, non-turbulent water mass passed through our sampling grid, we would have predicted an increase in nutrient concentrations ranging from 2 to $56 \%$ of initial values $\left(\mathrm{NH}_{4}^{+}\right.$and $\mathrm{NO}_{3}^{-}+\mathrm{NO}_{2}^{-} 56 \%$, $\mathrm{PO}_{4}^{3-} 7 \%$, and DON $2 \%$, respectively) based on knowledge of the mean water velocity ( $17 \mathrm{~h}$ transit time) and mean benthic nutrient flux.

\section{DISCUSSION}

Concrete collars bound to the hard bottom substrata and domes with sides constructed of thin mylar cloth proved to be an excellent design for studying material fluxes across the sediment/water interface. Not only was it possible to establish an effective seal between bell jar and a rough, irregular bottom surface, but by flexing like an accordion in response to underwater currents, the domes effectively stirred themselves thereby preventing the development of concentration gradients within the enclosed water (as visually witnessed following rhodamine injection).

Material in the water column is variable and dependent on the local behavior of nearshore fronts. During our observations in summer, the average concentrations of chl a and dissolved inorganic and organic nitrogen were similar to those from previous studies at this season and distance from shore, with the exception of phosphate-P, which was ca $50 \%$ higher (Oertel \& Dunstan 1981, Atkinson 1985, Yoder 1985). Observations of marsh grass detritus on the bottom indicated that there are occasional contributions of material from the coastal zone.

Comparisons between our study and those conducted in sandy regions of the Georgia Bight indicate the rich nature of Gray's Reef relative to the oligotrophic palimpsest sands of the majority of the shelf (Frankenberg 1971, Frankenberg \& Leiper 1977. Tenore et al. 1978, Hanson et al. 1981, Wenner et al. 1983). Mean chl a values of 7.3 and $14.2 \mu \mathrm{g} \mathrm{g}^{-1}$ dry wt for low- and medium-density portions of Gray's Reef were up to 5 times higher than the 2.4 to $2.6 \mu \mathrm{g} \mathrm{chl} \mathrm{a}$ $\mathrm{g}^{-1}$ dry wt range measured in surrounding sand habitats (Tenore et al. 1978, Hanson et al. 1981). While mean macro-infaunal biomass was $1.6 \mathrm{~g} \mathrm{C} \mathrm{m}^{-2}$ in sandy shelf regions (Hanson et al. 1981), macro-epifaunal biomass in low- to medium-dense regions of Gray's Reef ranged between 27 and $77 \mathrm{~g} \mathrm{C} \mathrm{m}^{-2}$ (Table 2). Organic carbon levels in Gray's Reef sands [0.63 $\mathrm{mg} \mathrm{C} \mathrm{g}^{-1}$ dry wt $(\mathrm{C}=37 \%$ of ash-free dry weight)] were substantially higher than in the sands at inner and mid-shelf regions ( $<1$ to $0.3 \mathrm{mg} \mathrm{C} \mathrm{g}^{-1}$ dry wt; Pinet \& Frey 1977, Hanson et al. 1981).

Pelagic primary production in the Georgia Bight is strongly dependent on nitrogen availability (Haines \& Dunstan 1975, Yoder 1985). Outwelling from the nearshore region and advection of upwelled water from Gulf Stream waters are the main supplies of 'new' nitrogen, resulting in higher production along the inner and outer edges of the shelf, with often lower production in the mid-shelf region (Yoder 1985). The high level of production we measured at Gray's Reef $(2.15 \mathrm{~g}$ $C \mathrm{~m}^{-2} \mathrm{~d}^{-1}$ ) may be indicative of hydrographic coupling with the nearshore region, since productivity is generally $<300 \mathrm{mg} \mathrm{C} \mathrm{m} \mathrm{m}^{-2} \mathrm{~d}^{-1}$ further offshore (Thomas 1970 , Turner et al. 1979). Planktonic respiration and pelagic ammonium regeneration were high relative to most coastal regions (Hanson \& Robertson 1988) but less than was observed by Hopkinson (1985) in the estuarine plume region of the nearshore Georgia Bight. The overall high levels of production, respiration and nutrient recycling in the Gray's Reef water column, which are in contrast to the generally low levels found in the mid-shelf region, suggest the influence of coupling with the nearshore region.

We observed substantial differences on the bottom that were related to the spatial distribution of epifaunal biomass. Metabolism and nutrient regeneration in the low-density sites were similar to rates measured by Fallon \& Hopkinson (unpubl.) in bare sand regions adjacent to the reef. However, rates were several orders of magnitude higher in the medium-density region. These rates are comparable to those found in the organically richer estuarine-plume portion of the nearshore continental shelf just $1.6 \mathrm{~km}$ off Sapelo Island (Hopkinson 1985). Although metabolism and nutrient regeneration were high in the medium-density region, they were only $1 / 4$ to $1 / 2$ as high as is common for tropical coral reef systems (Kinsey 1985).

The high respiratory and regenerative rates in the medium-density region relative to bare-sand and lowdensity regions are indicative of the importance of active epifaunal filter-feeding from the water column, as sedimentary inputs of organics would be comparably low throughout Gray's Reef. Even the relatively incomplete list of species in Table 1 reveals the pre- 
dominance of filter-feeders. Our present data do not give credit to the probable high density of mussels, especially of the genus Arca. During the first exploratory dives, the visible absence of mussels seemed peculiar until the sudden and strong movement of a gorgonian coral indicated that the mussels constituted a discontinuous and movable substrate upon which many other sessile forms grew. The dense cover of crust-like animals and sessile microalgae constitute a perfect camouflage. Although it was not measured, we can assume that sedimentation would be lower than that predicted from the level of primary production and the depth of the water column (Hargrave 1973), because high current velocities tend to increase the residence time of particles in the water column and hence the degree to which organic particles are decomposed in the water column (Hopkinson 1985). The difference in flux ratios of $\mathrm{N}$ and $\mathrm{P}$ between low-and medium-density sites may reflect a greater importance of processes within the sediments in the sandier sites, as opposed to activity concentrated on or above the sediment surface in medium-density regions. As oxygen is frequently limiting in subsurface sediments due to respiratory demand exceeding oxygen resupply, loss of $\mathrm{N}$ due to denitrification may contribute to the lower inorganic N:P ratio seen at the low-density location (Table 5).

\section{Net system heterotrophy at Gray's Reef}

During the period of our investigation, pelagic production was insufficient to meet respiratory demands of the planktonic community (Table 8). If we assume that the ${ }^{14} \mathrm{C}$ technique for measuring primary production yields an estimate of net production rather than gross production and assume that autotrophic respiration amounts to $10 \%$ of gross production (Burris 1980), the water column still appears to have been net heterotrophic, with community respiration exceeding primary production by ca $15 \%$ [production:respiration $(P: R)=$ $0.85: 1]$. Thus the water column was dependent on organic matter either imported from outside the system or accumulated as biomass during an earlier period of autotrophy. Hopkinson (1985) noted that the pelagic community in the nearshore region of the Georgia Bight was similarly heterotrophic at this time of year and presumably sustained by an earlier late-spring period of autotrophy

The benthic community of Gray's Reef was markedly heterotrophic, consuming almost twice as much organic matter as was produced on the bottom ( $\mathrm{P}: \mathrm{R}=$ $0.52: 1$, Table 8). This is not surprising for a coastal community operating at this depth and dominated by filter-feeders. Particulate organic carbon in the water
Table 8. Whole- and subsystem estimates of community metabolism for Gray's Reef. Whole-system estimates take into consideration water column depth and relative areas of bare sand, and low-density and medium-density hard bottom regions within the sanctuary. Prod.: production; resp.: respiration; $\mathrm{P}: \mathrm{R}=$ production respiration

\begin{tabular}{|cc|}
\hline $\begin{array}{c}\text { Systern } \\
\text { Parameter }\end{array}$ & $\begin{array}{c}\text { Metabolism } \\
\left(\mathrm{g} \mathrm{C}^{-2} \mathrm{~d}^{-1}\right)\end{array}$ \\
\hline Water column & \\
Primary prod. & 2.15 \\
Community resp. & -2.84 \\
Net community prod. & -0.69 \\
P:R & 0.76 \\
Benthos & \\
Primary prod. & 0.67 \\
Community resp. & -1.29 \\
Net community prod. & -0.63 \\
P:R & 0.52 \\
Gray's Reef system & \\
Primary prod. & 2.82 \\
Community resp. & -4.13 \\
Net community prod. & -1.32 \\
P:R & 0.68 \\
\hline
\end{tabular}

column (64 mmol $\mathrm{C} \mathrm{m}^{-2}$ ) could sustain the benthic community's level of net community production (-53 mmol $\left.\mathrm{C} \mathrm{m}^{-2} \mathrm{~d}^{-1}\right)$ for over a day, even in the absence of horizontal water movement. As our measurements were only conducted during summer we do not know if the benthos is heterotrophic throughout the year. Although macroalgae were visually more abundant during late winter and early spring we strongly doubt that benthic autotrophic production ever approaches the level of community respiration.

It is evident from Table 8 that the entire Gray's Reef system is heterotrophic and strongly dependent on allochthonous organic carbon for support of almost a third of its total respiratory requirements ( $P: R=0.68: 1$ ). Although community respiration is more than twice as high in the water column than on the bottom, production nearly balances respiration in the water column, while the benthic community consumes more than twice as much as it produces. Overall, the benthic and pelagic systems require similar quantities of organic matter to sustain their respiration levels, and the Gray's Reef ecosystem as a whole consumes $1.32 \mathrm{~g} \mathrm{C} \mathrm{m}^{-2} \mathrm{~d}^{-1}$ in excess of what it produces. It is thus strongly dependent on carbon produced elsewhere on the continental shelf.

Possible sources of this allochthonous organic matter are (1) primary production supported by 'new' nutrient inputs from terrestrial runoff and from Gulf Stream intrusions/upwellings, (2) organic matter inputs from rivers and coastal marshes and (3) primary production carried in by ocean currents from regions to the north or 
south of the Georgia Bight. As long as currents carry allochthonous organic material to Gray's Reef, the hard bottom system can sustain a heterotrophic balance, with respiration exceeding primary productivity and inorganic nutrient export exceeding import.

\section{Relative importance of biological and physical processes in controlling nutrients at Gray's Reef}

The dominance of the pelagial at Gray's Reef is illustrated by comparing the influence of advective, pelagic and benthic nutrient fluxes on the turnover times of inorganic nitrogen in the water column. Confining our attention to the representative portion of the reef where we sought to determine spatial patterns of nutrient distribution ( $8.57 \mathrm{~km}^{2}$ area - see Fig. 2 ), we calculate a conservative water turnover time of $15 \mathrm{~h}$. By definition this is also the advective turnover time of nutrients within the control volume. The turnover of nutrients due to biological activity in the water column is almost twice as rapid. On the basis of measured rates of primary productivity and assuming $N$ is taken up at a 106:16 C : $\mathrm{N}$ ratio, the turnover time of inorganic $\mathrm{N}$ in the water column due to phytoplankton uptake is $9.4 \mathrm{~h}$. The turnover time due to planktonic ammonium regeneration is about the same $(7.8 \mathrm{~h})$. In contrast, the turnover time due to the net flux of inorganic $N$ from the hard bottom community is $30 \mathrm{~h}$. Thus for our control volume over Gray's Reef, biological and physical processes in the water column have a much greater influence on water-column nutrient concentrations than do benthic processes. N flow associated with planktonic uptake and regeneration is 3.2 and 3.8 times greater than net benthic regeneration, while the advective input of $\mathrm{N}$ is 2.0 times greater.

\section{Comparison with coral reefs}

Beyond the presence of sessile filter-feeding sponges and corals, Gray's Reef has little direct similarity with well-studied tropical coral reefs. Coral reefs are generally considered to be energetically self-sustaining systems that accumulate and tightly recycle essential nutrients (Odum 1971). Metabolism in coral reef systems is dominated by benthic processes. While total primary production ranges between 2 and $12 \mathrm{~g} \mathrm{C} \mathrm{m}^{-2}$ $\mathrm{d}^{-1}$ (Lewis 1977), phytoplankton production is relatively trivial (Lewis 1977, Kinsey 1985). Although Gray's Reef has a total production level within the range noted for coral reefs, the majority (ca 76\%) is attributable to phytoplankton as opposed to benthic producers, including zooxanthellae. Whereas there are distinct zones within coral reefs acting as sources and sinks of carbon with respect to one another, coral reef systems overall exhibit a virtual balance between production and respiration over extended periods of time (Kinsey 1985, Smith 1988). In contrast, both the subsystems and Gray's Reef as a whole were highly heterotrophic and strongly dependent on allochthonous sources of organic matter. In coral reef systems the supply of oceanic materials, organic or inorganic, is small and export of organic material cannot exceed that input. High levels of gross production are physically juxtaposed with equally high levels of respiration, suggesting efficient cycling of nutrients, low net production and insignificant external coupling (Smith 1988). Gray's Reef demonstrates little capacity for either internal storage or recycling of nutrients; rather, it exports substantial quantities of inorganic nutrients to downstream pelagic systems. Finally, unlike coral reefs which involve real reef growth in space and time, largely due to coral and coralline algae, Gray's Reef is a structural feature formed of detrital sediments, growing in neither space nor time (Pilkey \& Frankenberg 1964).

\section{Implications for fisheries}

Regions of the continental shelf in the Georgia Bight with hard bottoms are generally characterized by large numbers, biomass and diversity of fishes (BLM 1981). That up to $30 \%$ of the shelf surface area is comprised of such bottoms (Miller \& Richards 1979, Parker et al. 1983) would suggest from first considerations than the total commercial fishery harvest in the Georgia Bight should be high. An analysis of U.S. commercial landings, however, suggests that fisheries production in the Georgia Bight is unusually low.

Commercial landings (edible and industrial) by U.S. fishermen at ports in the 4 states between Cape Hatteras, North Carolina, and Key West, Florida, have historically been substantially lower than landings at ports in any other region of the United States (NMFS 1986). As shown in Fig. 6A, there is a positive relationship between fish landings in various states and the tidal shoreline length of each state. Only 3 coastal states in the USA have landings lower than Georgia or South Carolina. By grouping landings into fishery regions along the Atlantic and Gulf of Mexico coasts, we find that for 3 of the 4 eastern and southeastern coastal regions of the USA, there is a positive curvilinear relationship between commercial landings and regional tidal shoreline length (Fig. 6B). Landings increase substantially going from north to south. The factors leading to this curvilinear relationship are unknown, but it may reflect increased pelagic productivity in the warmer southern waters and increased organic matter outwelling from Gulf of Mexico estuaries. Of particular interest 


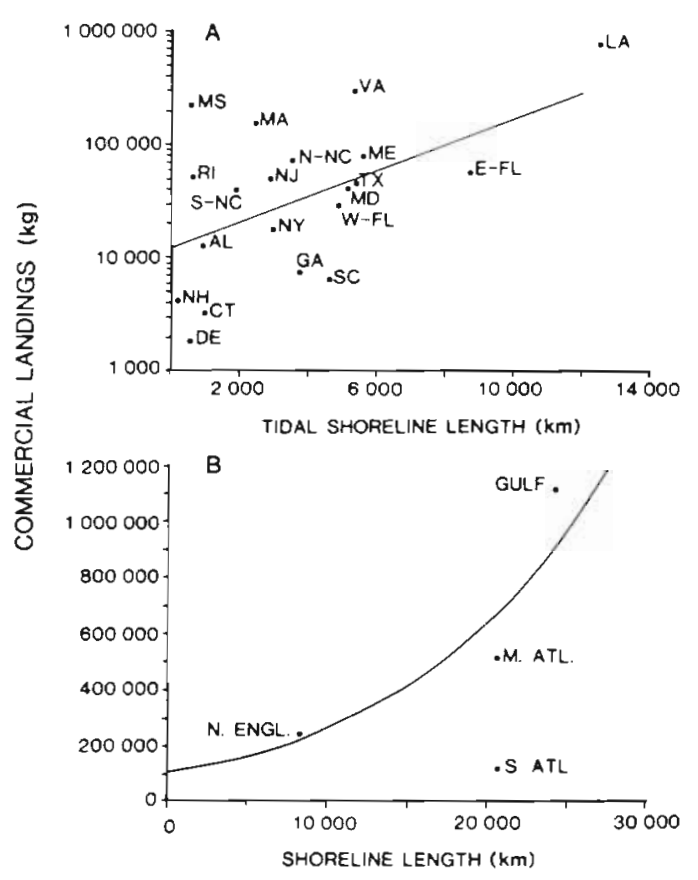

Fig. 6. Relationships between tidal shoreline length and commercial landings (edible and industrial) of fish and shellfish by U.S. fishermen along the Gulf and Atlantic coasts of the USA, (A) by state and (B) by region. AL: Alabama; CT: Connecticuti DE: Delaware; FL: Florida; GA: Georgia; LA: Louisiana; MA: Massachusetts; MD: Maryland; ME: Maine; MS: Mississippi; NC: North Carolina; NH: New Hampshire; NJ: New Jersey; NY: New York; RI: Rhode Island; SC: South Carolina; TX: Texas; VA: Virginia. New England region (N. ENGL) is from Massachusetts through Maine. Middle Atlantic (M. ATL) is from Cape Hatteras, North Carolina (N-NC), through Rhode Island. South Atlantic (S. ATL) is from Key West, Florida (EFL), to Cape Hatteras, North Carolina (S-NC). Gulf of Mexico (GULF) is the entire USA shoreline along the Gulf of Mexico including western Florida (W-FL). Curve in (A) from linear regression of $\log _{10}$ landings vs tidal shoreline length $\left(\mathrm{r}^{2}=\right.$ $0.41)$. Curve in (B) from linear regression of $\log _{10}$ regional landings vs tidal shoreline length, excluding the south Atlantic region $\left(r^{2}=0.93\right)$. Landings from 1984 and 1985

in Fig. 6B, however, is the fact that landings from the south Atlantic fishery region are substantially removed from the curvilinear relationship that exists for the other fishery regions. There is an apparent underproduction of the southeastern fishery (see Hopkinson et al. 1989).

Gray's Reef hard bottom was found to be substantially heterotrophic $(P: R=0.68)$, consuming $1.3 \mathrm{~g}$ $\mathrm{C} \mathrm{m}^{-2} \mathrm{~d}^{-1}$ more than was produced by pelagic and benthic primary producers (Table 8 ). A very large percentage of system biomass and respiration was attributable to filter-feeding organisms which are largely ungrazed, including corals, sponges and mussels (our assumption about lack of grazing is based on visual and photographic surveys of marked sites and organisms over a 3 yr period). Consequently it appears as though a net effect of hard bottom communities such as that found on Gray's Reef is the capture and removal of organic matter produced in the water column. As a result of being respired by ungrazed macrofauna, this organic matter becomes unavailable for support of either a benthic or planktonic food chain leading to the production of commercially important fishes.

As geological and faunistic studies of hard bottoms in the southeast indicate that Gray's Reef is a typical hard bottom habitat on the continental shelf (Wenner et al. 1983, Barans \& Henry 1984, Sedberry \& Van Dolah 1984), we may assume that other hard bottom communities across the southeastern continental shelf are functionally similar to Gray's Reef. Taken together these hard bottom habitats may contribute to what appears to be an underproduction of commercially important fishes. As up to $30 \%$ of the bottom area of the southeastern continental shelf is hard bottom, the gross removal of organic matter from the water column is potentially substantial. As average pelagic primary production across the Georgia Bight is $<1 \mathrm{~g} \mathrm{C} \mathrm{m}^{-2} \mathrm{~d}^{-1}$ (Haines \& Dunstan 1975, Yoder 1985), hard bottom communities may be responsible for consuming $1 / 3$ of total primary production in the water column. Thus the organic matter resource base upon which commercial fisheries in the southeastern portion of the USA must develop is smaller than that which would be available in the absence of hard bottom communities.

The abundance of fish on hard bottoms such as Gray's Reef and the hypothesis that hard bottoms contribute to the low commercial fisheries harvest in the Georgia Bight may appear to be contradictory. The apparent paradox is due to conclusions framed at 2 different levels of scale. At the small spatial scale of Gray's Reef, the abundance of fish found at Gray's Reef is due to (1) the presence of habitat (a lone cinder block or tire on an otherwise featureless sandy bottom will attract fish) and (2) benthic primary production (Table 8). Primary production on bare sand bottoms is extremely low in the Georgia Bight (Hopkinson 1985); thus even the moderate level of benthic primary production on Gray's Reef permits development of the food chain, leading to the conspicuous Gray's Reef fish community that would not be possible otherwise. At the scale of commercial fisheries harvest for the entire Georgia Bight, however, the important characteristics of Gray's Reef are that (1) overall the system is markedly heterotrophic and (2) the dominance of system respiration is largely due to ungrazed heterotrophs which filter allochthonous organic matter from the water column. Very high levels of respiration by filter-feeders are not nearly balanced by the moderate levels of benthic primary production and thus, at the scalar level of the entire Georgia Bight, hard bottoms, functioning as trophic black holes, can theoretically depress fish production of the overall shelf. 
Acknowledgements. A project of this magnitude conducted at sea required the assistance of a great number of individuals both in front of and behind the scenes. We wish to show gratitude especially to Captains Johnny Harris and George Walker, divers Pelle Jansson, Carl Fitz, Laura Pittman, Rick Hoffman, and Laurel Berger, laboratory assistants Janet Fallon and Steve Kipp, site specialists Nick Nicholson, Henry Ansley and Duane Harris, logistics supervisor Charles Durant and cartographers Lorene Gassert, Eileen Hedick, and Bob Golder. We appreciate the constructive criticism of Evelyn Sherr, Barry Sherr, William Wiebe, and James Porter This research was sponsored by NOAA, U.S. Department of Commerce, Office of Ocean and Coastal Resource Management, Sanctuary Programs Division, under grant No. NA84AA-HCZ027 and Office of Sea Grant, Department of Commerce, under grant No. NA80AA-D-00091.

\section{LITERATURE CITED}

Atkinson, L. P. (1985). Hydrography and nutrients of the southeastern U.S. continental shelf. In: Atkinson, L. P., Menzel, D. W. Bush, K. A. (eds.) Oceanography of the southeastern U.S. continental shelf. Coastal and Estuarine Sciences, Vol.2. American Geophysical Union, Washington, D.C., p. 72-92

Barans, C., Henry, V. J. (1984). A description of the shelf edge groundfish habitat along the southeastern United States. NE. Gulf Sci. 7: 77-96

Blackburn, T. H. (1979). Method for measuring rates of $\mathrm{NH}_{4}^{+}$ turnover in anoxic marine sediments, using a ${ }^{15} \mathrm{~N}-\mathrm{NH}_{4}^{+}$ dilution technique. Appl. environ. Microbiol. 37: 760-765

BLM (Bureau of Land Management, U.S. Department of Interior) (1981). Final report. South Atlantic outer continental shelf area living marine resources study, Vols. I, II, \& III. U.S. Department of the Interior, Washington, D.C.

Burris, J. (1980). Respiration and photorespiration in marine algae. In: Falkowski, P. (ed.) Primary productivity in the sea. Plenum Press, New York, p. 411-432

Cain, T D. (1972). Additional epifauna of a reef off North Carolina. J. Elisha Mitchell scient. Soc. 88: 79-82

Caperon, J., Schell, D., Hirota, J., Laws, E. (1979). Ammonium excretion rates in Kaneohe Bay, Hawaii, measured by a ${ }^{15} \mathrm{~N}$ isotope dilution technique. Mar. Biol. 54: 33-40

Dudek, N., Brzezinski, M. A., Wheeler, P. A. (1986). Recovery of ammonium nitrogen by solvent extraction for the determination of relative ${ }^{15} \mathrm{~N}$ abundance in regeneration experiments. Mar. Chem. 18 (1): 59-69

Fallon, R. D., Hopkinson, C. (1986). Community metabolism and nutrient fluxes at Gray's Reef National Marine Sanctuary. NOAA Technical Report Series OCRM/SPD. U.S. Department of Commerce, Sanctuary Programs Office, Washington, D.C

Frankenberg, D. (1971). The dynamics of benthic communities off Georgia, USA. Thallassia jugosl. (special volume) ?: 49-55

Frankenberg, D., Leiper, A. S. (1977). Seasonal cycles in benthic communities of the Georgia continental shelf. In Coull, B. (ed.) Ecology of marine benthos. University of South Carolina Press, Columbia, South Carolina

Grasshoff, K. (1976). Methods of seawater analysis. Verlag Chemie, New York.

Haines, E. B., Dunstan, W M. (1975). The distribution and relation of particulate organic material and primary productivity in the Georgia Bight 1973-74. Estuar. coast. mar Sci. 3: $431-441$
Hanson, R. B., Robertson, C. Y (1988). Spring recycling rates of ammonium in turbid continental shelf waters of southeastern United States. Contin. Shelf Res. 8: 49-68

Hanson, R. B., Tenore, K. R., Bishop, S., Chamberlain, C., Pamatmat, M. M. Tietjen, J. (1981). Benthic enrichment in the Georgia Bight related to Gulf Stream intrusions and estuarine outwelling. J. mar. Res. 39 (3): 417-441

Hargrave, B. T (1973). Coupling of carbon flow through some pelagic and benthic communities. J. Fish. Res. Bd Can. 30: $1317-1326$

Hedges, J., Stern, J. (1984). Carbon and nitrogen determination of carbonate-containing solids. Limnol. Oceanogr 29: $657-663$

Henry, V. J., Giles, R. T (1980). Distribution and occurrence of reefs and hardgrounds in the Georgia Bight. In: Opoenoe, P. J. (ed.) Final report: Environmental studies, southeastern United States outer continental shelf 1977: Geology. U.S. Geological Survey Open File Report 80-146, Washington, D.C., p. 8.1-8.36

Hopkinson, C. S. (1985). Shallow-water benthic and pelagic metabolism: evidence of heterotrophy in the nearshore Georgia Bight. Mar Biol. 87: 19-32

Hopkinson, C. S. (1987). Nutrient regeneration in shallowwater sediments of the estuarine plume region of the nearshore Georgia Bight, USA. Mar Biol. 94: 127-142

Hopkinson, C. S., Sherr, B., Wiebe, W. (1989). Size fractionated metabolism of coastal microbial plankton. Mar. Ecol. Prog. Ser. 51-155-166

Hunt, J. L. (1974). The geology and origin of Gray's Reef, Georgia continental shelf. M.Sc. thesis, University of Georgia, Athens, Georgia

Kinsey, D. W. (1985). Metabolism, calcification and carbon production. In: Gabrié, C. et al. (eds.) Proceedings 5th int. coral Reef Cong. Ephe Publishers, Moorea, French Polynesia, p. 503-526

Laws, E. A. (1984). Isotope dilution models and the mystery of the vanishing ${ }^{15} \mathrm{~N}$. Limnol. Oceanogr. 29: 379-385

Lewis, J. B. (1977). Processes of organic production on coral reefs. Biol. Rev. 52: 305-347

Menzies, R., Pilkey, E., Blackwelder, B., Dexter, D., Huling, P., McCloskey, L. (1966). A submerged reef off North Carolina. Int. Revue ges. Hydrobiol. 51. 393-431

Miller, G., Richards, W. (1979). Reef fish habitat, faunal assemblages and factors determining distributions in the South Atlantic Bight. Proc. Gulf Caribb. Fish. Inst. 32: $114-130$

NMFS (National Marine Fisheries Service) (1986). Fisheries of the United States, 1985. U.S. Dept. of Commerce, NOAA, NMFS, Washington, D.C.

NOAA (National Oceanic and Atmospheric Administration) (1980). An environmental impact statement on the proposed Gray's Reef Marine Sanctuary. U.S. Department of Commerce, Sanctuary Programs Office, Washington, D.C.

NOAA (National Oceanic and Atmospheric Administration) (1983). Gray's Reef National Marine Sanctuary management plan. U.S. Department of Commerce, Washington, D.C.

Odum, E. P. (1971). Fundamentals of ecology. W. B. Saunders, Philadelphia

Oertel, G. F., Dunstan, W. M. (1981). Suspended sediment distribution and certain aspects of phytoplankton production off Georgia, USA. Mar Geol. 40: 171-197

Parker, R, Colby, D., Willis, T (1983). Estimated amount of reef habitat on a portion of the U.S. South Atlantic and Gulf of Mexico continental shelf. Bull. mar Sci. 33: 935-940

Parsons, T., Takahashi, M., Hargrave, B. (1984). Biological oceanographic processes. Pergamon Press, New York 
Pearse, A., Williams, L. (1951). The biota of the reefs of the Carolinas. J. Elisha Mitchell scient. Soc. 67. 133-161

Peterson, B. J. (1978). Radiocarbon uptake: its relation to net particulate carbon production. Limnol. Oceanogr $23(1)$ : $179-184$

Pilkey, O., Frankenberg, D. (1964). The relict-recent sediment boundary in the Georgia continental shelf. Bull. Georgia Acad. Sci. 22: $37-40$

Pinet, P., Frey, R. (1977). Organic carbons in surface sands seaward of Altamaha and Doboy Sounds, Georgia. Bull. geol. Soc. Am. 88: 1731-1739

Searles, R. B. (1981). Seaweeds from Gray's Reef, Georgia. NE. Gulf Sci. 5: 45-48

Sedberry, G., Van Dolah, R. (1984). Demersal fish assemblages associated with hard bottom habitat in the South Atlantic Bight of the USA. Environ. Biol. Fish. 11: 1

Shoaf, W T., Lium, B. W. (1976). Improved extraction of chlorophyll $a$ and $b$ from algae using dimethyl sulfoxide. Limnol. Oceanogr: 21: 926-928

Smith, S. V. (1988). Mass balance in coral reef-dominated areas. In: Jansson, B.-O. (ed.) Coastal-offshore ecosystem interactions. Springer-Verlag, Berlin, p. 209-226

Strickland, J. D. H., Parsons, T. R. (1972). A practical handbook of seawater analysis, 2nd edn. Bull. Fish. Res. Bd Can. 167: 1-310

Tenore, K. R., Chamberlain, C. F., Dunstan, W. M., Hanson, R. B. Sherr, B., Tietjen, J. H. (1978). Possible effects of Gulf Stream

This article was presented by Drs B. Sherr and E. Sherr, Corvallis, Oregon, USA intrusions and coastal runoff on the benthos of the continental shelf of the Georgia Bight. In: Wiley, M. L. (ed.) Estuarine interactions. Academic Press, New York, p. 577-598

Thomas, J. P. (1970). Release of dissolved organic matter from natural populations of marine phytoplankton. Ph.D. dissertation, University of Georgia, Athens, Georgia

Turner, R. E., Woo, S. W., Jitts, H. R. (1979). Estuarine influences on a continental shelf plankton community. Science 206: 218-220

Uchupi, E. (1967). The continental margin south of Cape Hatteras, North Carolina: shallow structure. SE. Geol. 8: $155-177$

Wenner, E., Hinde, P., Knott, D., Van Dolah, R. (1984). A temporal and spatial study of invertebrate communities associated with hard-bottom habitats in the South Atlantic Bight. NOAA Technical Report NMFS 18. U.S. Department of Commerce, Washington, D.C.

Wenner, E., Knott, D., Van Dolah, R., Burrell, V. (1983). Invertebrate communities associated with hard bottom habitats in the South Atlantic Bight. Estuar coast. Shelf Sci. 17: 143-158

Yoder, J. A. (1985). Environmental control of phytoplankton production on the southeastern U.S. continental shelf. In: Atkinson, L. P., Menzel, D. W., Bush, K. A. (eds.) Oceanography of the southeastem U.S. continental shelf. Coastal and Estuarine Science, Vol.2. American Geophysical Union, Washington, D.C., p. 93-103

Manuscript first received: March 31, 1990

Revised version accepted: April 5, 1991 


\title{
Demersal assemblages of the continental shelf and slope edge between the Gulf of Tehuantepec (Mexico) and the Gulf of Papagayo (Costa Rica)
}

\author{
G. Bianchi \\ Institute of Marine Research, Division for International Development Programmes, PO Box 1870, Nordnes, N-5024 Bergen, \\ Norway
}

\begin{abstract}
The structure of demersal assemblages (fish, crustaceans and cephalopods) of the continental shelf and upper slope between the Gulf of Tehuantepec and the Gulf of Papagayo was studied from data obtained in the course of surveys carried out by the RV 'Dr. F. Nansen' in 1987, by means of an ordination technique, Detrended Correspondence Analysis (DCA) implemented by the program DECORANA, and a classification technique, Two-Way Indicator Species Analysis (TWIA) implemented by the program TWINSPAN. Three major groups of species were identified: those distributed above the thermocline, those within the range of the thermocline and a third group below the thermocline, where oxygen content is extremely low. Highest biomass densities were found below the thermocline, consisting mainly of the galatheid crustacean Pleuroncodes monodon (H. Milne Edwards, 1837). Correlation of DCA Axis 1 with depth, temperature, salinity and oxygen showed that depth is the main gradient along which faunal changes occur.
\end{abstract}

\section{INTRODUCTION}

Since 1975 the Norwegian RV 'Dr. F. Nansen' has carried out acoustic and trawl surveys of the continental shelves and upper slopes of many tropical countries. The present study is the first of a series based on material from these surveys, investigating the structure of demersal assemblages in relation to principal environmental variables and geographical location. The taxa included in the analysis are bony and cartilaginous fishes, stomatopods, decapod crustaceans and cephalopods.

As pointed out by Caddy \& Sharp (1986), this type of study is a necessary step toward understanding of multispecies stocks. Such work can then be extended to 'descriptive community dynamics' (McManus 1985) in order to find general patterns of which species compositions can be expected under given environmental conditions and fishing effort. Comparison of assemblages from similar ecosystems in different areas might also reveal general trends in the community dynamics of tropical shelves.

In addition, this work could be useful in fisheries management. For example, species composition of trawl catches from a given study area may be roughly anticipated from assemblage maps derived from the analysis, especially for those areas most recently investigated.

Studies of tropical fish community structure by means of multivariate analysis (excluding coral reef areas and lagoon systems) have been carried out in the Gulf of Guinea (Fager \& Longhurst 1968), Namibia (Lleonart \& Roel 1984), upwelling areas of West Africa (Roel et al. 1985), the Gulf of Nicoya, Costa Rica (Bartels et al. 1983), the Samar Sea, Philippines (McManus 1985), Malaysia (Chan \& Liew 1986), northern Australia (Rainer \& Munro 1982 and Rainer 1984) and northwestern Australia (Sainsbury 1987).

To the author's knowledge, no other studies of shelf assemblages have covered the area considered in the present work, i.e. the shelf between the Gulf of Tehuantepec and the Gulf of Papagayo. Bartels et al. (1983) described the occurrence, distribution, abundance and diversity of fish assemblages in the Gulf of Nicoya, Costa Rica. Studies on fish community structure in coastal lagoon systems on the Pacific coast of Mexico were carried out by Warburton (1978), YanezArancibia (1978 a, b) and Chavez (1979). 